\title{
Zinc absorption in adult humans: the effect of protein sources added to liquid test meals
}

\author{
BY LENA DAVIDSSON ${ }^{*}$, ANNETTE ALMGREN ${ }^{2}$, \\ BRITTMARIE SANDSTRÖM ${ }^{3}$, MARCEL-A. JUILLERAT ${ }^{1}$ \\ AND RICHARD F. HURRELL ${ }^{1 *}$ \\ ${ }^{1}$ Nestec Ltd, Nestlé Research Centre, PO Box 44, CH-1000 Lausanne 26, Switzerland \\ ${ }^{2}$ Department of Clinical Nutrition, Gothenburg University, Annedalsklinikerna, \\ S-41345 Göteborg, Sweden \\ ${ }^{3}$ Research Department of Human Nutrition, The Royal Veterinary and Agricultural University, \\ Rolighedsvej 25, DK-1958 Fredriksberg, Denmark
}

(Received 8 December 1994 - Revised 18 May 1995 - Accepted 21 July 1995)

\begin{abstract}
The influence of different protein sources on $\mathrm{Zn}$ absorption was evaluated in healthy adults by radioisotopic labelling of single meals, followed by whole-body retention measurements $14 \mathrm{~d}$ after intake. Semi-synthetic liquid diets were used for the evaluation of different animal-protein sources and dephytinized soyabean-protein isolate $(<0.01 \mathrm{~g}$ phytic acid/kg). Zn absorption was measured in the same subjects from identical test meals containing no added protein. No statistically significant differences were found in the $\mathrm{Zn}$ absorption from test meals containing bovine whey, casein or egg albumen when compared with test meals without added protein. Bovine serum albumin (BSA) and soyabean-protein isolate ( $<0.01 \mathrm{~g}$ phytic acid $/ \mathbf{k g}$ ) significantly reduced the mean absorption of $\mathrm{Zn}$ from $45-49 \%$ (no added protein) to 38.0 (SD 10.9) (BSA, $P<0.05$ ) and 33.9 (SD 12.6) \% (soyabean-protein isolate $<0.01 \mathrm{~g}$ phytic acid $/ \mathrm{kg}, P<0.01$ ). These results demonstrate that $\mathrm{Zn}$ absorption is inhibited by certain protein sources, such as BSA and dephytinized soyabean-protein isolate, while other proteins have little or no effect.
\end{abstract}

Zinc: Protein: Radioisotope

The bioavailability of $\mathrm{Zn}$ is, as for other minerals, dependent on the net effect of dietary factors which enhance or inhibit its absorption and utilization. Soluble low-molecularweight compounds such as amino acids, peptides and organic acids in foods have been proposed to act as $\mathrm{Zn}$-binding ligands, which increase $\mathrm{Zn}$ absorption (Sandström et al. $1980,1983,1985)$. Other ligands, such as phytic acid, form insoluble $\mathrm{Zn}$-complexes in the intestine from which $\mathrm{Zn}$ is unavailable for absorption (Sandström et al. 1980; Lönnerdal et al. 1984; Nävert et al. 1985).

Optimum $\mathrm{Zn}$ nutrition is of particular importance for the rapidly growing infant and the effect of the dietary components present in infant formula and weaning foods on $\mathrm{Zn}$ bioavailability is an important consideration when formulating these products. One component of infant foods which could influence $\mathrm{Zn}$ absorption is the dietary protein source. Several isolated proteins could be used, e.g. bovine casein, bovine whey and

\footnotetext{
* Present address: Laboratory for Human Nutrition, Swiss Federal Institute of Technology, Box 474, CH-8803 Rüschlikon, Switzerland.
} 
soyabean-protein isolate, and so far there has been no systematic evaluation of the effect of isolated proteins on $\mathrm{Zn}$ absorption. Fe-absorption studies in adult humans, however, have demonstrated a strong inhibitory effect of proteins such as soyabean, bovine casein and egg albumen when added to a liquid test meal and compared with absorption values from a reference meal containing no protein (Hurrell et al. 1989, 1990, 1992) and it could be speculated that $\mathrm{Zn}$ absorption might be affected in a similar way.

Infant formulas based on soyabean-protein isolate are of special concern since $\mathrm{Zn}$ absorption from soyabean formulas has been reported to be significantly lower than that from human milk and cow's milk formula when studied in adult humans (Sandström et al. 1983; Lönnerdal et al. 1984). So far no evaluation of the inhibitory effect of soyabeanprotein isolate on $\mathrm{Zn}$ absorption has been done to separate the effect of the protein per se from that of the relatively high content of phytic acid in soyabean-protein isolate. Recent studies have demonstrated that phytic-acid-free soyabean conglycinin per se is inhibitory to Fe absorption in humans (Lynch et al. 1995).

The present study was undertaken to evaluate the effect on $\mathrm{Zn}$ absorption of different isolated proteins added to a liquid, semi-synthetic test meal consisting of hydrolysed maize starch, maize oil, protein source and water. The protein sources included bovine whey and casein, bovine serum albumin (BSA), egg albumen and dephytinized soyabean-protein isolate. Comparisons were made with identical test meals without added protein. $\mathrm{Zn}$ absorption was measured in healthy adult volunteers by a radionuclide technique from liquid test meals labelled with ${ }^{65} \mathrm{Zn}$.

\section{MATERIALS AND METHODS}

\section{Subjects}

Forty healthy adult volunteers (twenty women and twenty men; mean age 26 years, range 19-40 years) participated in five separate $\mathrm{Zn}$-absorption studies, each study having eight subjects. Paired comparisons were made with each subject acting as his or her own control. All were apparently healthy, non-pregnant, and had no known gastrointestinal disorders. The subjects were given oral and written information about the aims and procedures of the study, which was approved by the Isotope Committee at Sahlgren's Hospital, Göteborg.

\section{Test meals}

Semi-synthetic test meals. Demineralized bovine whey was prepared from a whey-protein concentrate (Lacprodan 80, Danmark Protein, Videback, Denmark) by the addition of cation and anion exchange resins (Amberlite, $\mathrm{H}+$ and $\mathrm{OH}-$ form, Fluka, Buchs, Switzerland). The resins were removed by filtering after completed demineralization of the protein sources. The demineralized proteins were heat-treated ( $70^{\circ}$ for $30 \mathrm{~min}$ ) before being freeze-dried. Sodium caseinate with a low inorganic phosphate content (bovine casein) was prepared from commercial sodium caseinate (Emmi A. G., Dagmersellen, Switzerland), using the same procedure as for the preparation of demineralized whey. The soyabeanprotein isolate was prepared from defatted soyabean flour by isoelectric precipitation. Dephytinized soyabean isolate was prepared by treating the fresh isolate with phytase (EC 3.1.3.8). The enzyme (derived from Aspergillus niger) was purchased from Alko Ltd. (Helsinki, Finland). All protein sources were shown to be microbiologically safe before being used in the Zn-absorption studies. BSA (fraction V) and egg white were purchased from Sigma, St. Louis, MO, USA and Monarch Egg Corporation, Kansas City, MO, USA respectively. 
The semi-synthetic test meals used in the present study were prepared as described by Cook \& Monsen (1976), with slight modifications. Each test meal consisted of $30 \mathrm{~g}$ crude protein from one of the protein sources, $67 \mathrm{~g}$ hydrolysed maize starch (Fro-Dex, American Maize Products, Hammond, IN, USA), $35 \mathrm{~g}$ maize oil, $200 \mathrm{~g}$ deionized distilled water and $12 \mathrm{~g}$ vanilla extract (McCormick and Co., Baltimore, MD, USA). The $\mathrm{Zn}$ content was adjusted to the same level in all the semi-synthetic test meals since a significant correlation between $\mathrm{Zn}$ absorption and $\mathrm{Zn}$ content has been demonstrated in test meals containing animal protein (Sandström \& Cederblad, 1980). The total contents of $\mathrm{Zn}, \mathrm{Fe}$ and $\mathrm{Ca}$ were kept constant at 30,90 and $748 \mu \mathrm{mol}$ per serving by addition of $\mathrm{ZnCl}_{2}, \mathrm{FeCl}_{2} \cdot 4 \mathrm{H}_{2} \mathrm{O}$ and $\mathrm{CaCl}_{2} \cdot 2 \mathrm{H}_{2} \mathrm{O}$ (Merck, Darmstadt, Germany).

Extrinsic labelling of test meals. Each test meal was extrinsically labelled with $0.05 \mathrm{MBq}$ ${ }^{65} \mathrm{Zn}$ (first test meal) or $0.1 \mathrm{MBq}{ }^{65} \mathrm{Zn}$ (second test meal) by adding almost-carrier-free ${ }^{65} \mathrm{ZnCl}_{2}$ solution (3.7-92.5 MBq/mg Zn; Amersham International, Bucks.) during preparation of the test meals. The semi-synthetic test meals were labelled $16-18 \mathrm{~h}$ before consumption. The activity of each individual test meal was measured in the whole-body counter before being served. All administrations of labelled test meals were done under close supervision by one of the investigators to ensure that the entire serving was consumed. Leftovers were measured in the whole-body counter in order to calculate the exact dose of radioactivity consumed by each subject. The effective dose equivalent was calculated for each subject according to the data given by the International Commission on Radiological Protection (1987) and based on individual $\mathrm{Zn}$ absorption values.

\section{Zinc absorption measurements}

$\mathrm{Zn}$ absorption was measured according to the method of Arvidsson et al. (1978). This method is based on the measurement of whole-body retention approximately $14 \mathrm{~d}$ after administration of a labelled test meal. Each subject's background radioactivity was measured before intake of the labelled test meal. The subjects were randomly allocated to the different test meals which were served after an overnight fast. No food or drink was allowed until $3 \mathrm{~h}$ after intake of the test meals. The whole-body retention was measured 10-14 d after intake of each test meal to allow for excretion of the non-absorbed fraction. Corrections were made for the excretion of initially absorbed isotope during the time between intake and retention measurements using the mean rate of excretion of an intravenously administered dose of ${ }^{65} \mathrm{Zn}$ in a similar group of subjects (Arvidsson et al. 1978). The mean correction corresponded to an excretion of $11-13 \%$ of the absorbed dose 10-14 d after intake. After intake of the second test meal (about $14 \mathrm{~d}$ after intake of the first test meal), allowance was also made for the excretion of the residual radioactivity from the first test meal.

\section{Food analysis}

Samples of the protein sources and other meal components were analysed in duplicate for their content of $\mathrm{Zn}, \mathrm{Fe}$ and $\mathrm{Ca}$ by atomic absorption spectrometry (AAS: Perkin Elmer Model 360, Perkin Elmer, Uberlingen, Germany). Portions were wet-ashed in quartz flasks with a mixture of $1 \mathrm{ml} 18 \mathrm{M} \mathrm{H}_{2} \mathrm{SO}_{4}-2 \mathrm{ml} 9.8 \mathrm{M} \mathrm{H}_{2} \mathrm{O}_{2}$ at $300^{\circ}$. The samples were diluted to $75 \mathrm{ml}$ with ultra pure water and lanthanum oxide was added to the mineralized samples equivalent to a final concentration of $10 \mathrm{~g}$ lanthanum/1 before analysis of $\mathrm{Ca}$. $\mathrm{Zn}$ and $\mathrm{Fe}$ were analysed after dry-ashing the samples in quartz flasks in a muffle furnace at $450^{\circ}$ for $48 \mathrm{~h}$. Ash was dissolved in $5 \mathrm{ml} 5 \mathrm{M}-\mathrm{HCl}$ and diluted to $25 \mathrm{ml}$ with ultra pure water. Accuracy of the methods was tested by analysing the standard reference material Total Diet (Agricultural Research Centre of Finland Central Laboratory, Jokioinen, Finland). The analysed values 
Table 1. Contents of nitrogen, calcium, zinc, iron and phytic acid (per $\mathrm{kg}$ ' as is') in the different protein sources

\begin{tabular}{lccccc}
\hline Protein source & $\begin{array}{c}\text { Nitrogen } \\
(\mathrm{g} / \mathrm{kg})\end{array}$ & $\begin{array}{c}\text { Calcium } \\
(\mathrm{mmol} / \mathrm{kg})\end{array}$ & $\begin{array}{c}\text { Zinc } \\
(\mu \mathrm{mol} / \mathrm{kg})\end{array}$ & $\begin{array}{c}\text { Iron } \\
(\mu \mathrm{mol} / \mathrm{kg})\end{array}$ & $\begin{array}{c}\text { Phytic acid } \\
(\mathrm{g} / \mathrm{kg})\end{array}$ \\
\hline Bovine whey & 115 & 6 & 28 & $<20$ & - \\
Bovine casein & 148 & 1 & 207 & 266 & - \\
BSA & 160 & 2 & $<1$ & 158 & - \\
Egg albumen & 129 & 13 & 15 & 49 & $<-$ \\
Soyabean-protein isolate & 150 & 10 & 673 & 2472 & $<0.01$ \\
\hline
\end{tabular}

BSA, bovine serum albumin.

for $\mathrm{Zn} \mathrm{(448} \mathrm{(SD} \mathrm{30)} \mu \mathrm{mol} / \mathrm{kg}$ ), Fe (524 (SD 15) $\mu \mathrm{mol} / \mathrm{kg}$ ) and Ca (72 (SD 3) mmol $/ \mathrm{kg}$ ) were in agreement with the certified values, 442 (SD 20) $\mu \mathrm{mol} \mathrm{Zn} / \mathrm{kg}, 544$ (SD 16) $\mu \mathrm{mol} \mathrm{Fe} / \mathrm{kg}$ and 71 (SD 3) mmol Ca/kg. $\mathrm{N}$ was analysed by a micro-Kjeldahl technique (Technicon Auto Analyzer, Technicon AB, Stockholm, Sweden). Crude protein was calculated by applying the factor 6.25 to the $\mathrm{N}$ values. Phytic acid was measured by cerium (IV) sulphate precipitation according to a modification of the method by Makover (1970).

\section{Blood analysis}

Serum $\mathrm{Zn}$ was measured in samples drawn from all subjects on the first day of the study after an overnight fast. Serum was diluted five times with ultra pure water before AAS analysis (Perkin Elmer Model 360). Seronorm serum batch no. 164 (Nyegaard \& Co., Torshov, Norway) was analysed together with the serum samples. The analysed values $(11.5(\mathrm{SD} 0.3) \mu \mathrm{mol} / 1)$ were in agreement with the certified value of $11.0 \mu \mathrm{mol} / 1$.

\section{Statistical methods}

Zn absorption values are given as means and standard deviations. Student's $t$ test for paired observations was used for statistical comparisons. Statistical significance is given at the $P<0.05$ level.

\section{RESULTS}

All subjects were found to have serum-Zn concentrations within the normal range for women (9-15 $\mu \mathrm{mol} / 1)$ and men (9-18 $\mu \mathrm{mol} / 1)$ in our laboratory. The contents of $\mathrm{N}, \mathrm{Zn}, \mathrm{Ca}$ and $\mathrm{Fe}$ in the different protein sources, as well as phytic acid in the soyabean-protein isolate, are given in Table 1 . The hydrolysed maize starch contained $6 \mu \mathrm{mol} \mathrm{Zn}, 1 \mathrm{mmol} \mathrm{Ca}$ and $29 \mu \mathrm{mol} \mathrm{Fe} / \mathrm{kg}$. The mineral content of the vanilla extract was $15 \mu \mathrm{mol} \mathrm{Zn}, 3 \mathrm{mmol} \mathrm{Ca}$ and $11 \mu \mathrm{mol} \mathrm{Fe} / \mathrm{kg}$. No $\mathrm{N}$ was detected in either of these samples.

The fractional $\mathrm{Zn}$ absorption values for the individual test meals are summarized in Table 2. Zn absorption was not significantly affected by addition of bovine whey, bovine casein or egg albumen when compared with similar protein-free test meals. However, a statistically significant reduction of $\mathrm{Zn}$ absorption was found when BSA or dephytinized soyabean-protein isolate $(<0.01 \mathrm{~g}$ phytic acid $/ \mathrm{kg})$ were included in the test meal. The mean fractional absorption decreased from $45-49 \%$ (no protein) to $38.0(\mathrm{SD} 10.9) \%$ (BSA, $P<0.05$ ) and 33.9 (SD 12.6) \% (soyabean-protein isolate $<0.01 \mathrm{~g}$ phytic acid $/ \mathrm{kg}$, $P<0.05)$.

The effective dose equivalent was calculated to be $0 \cdot 36$ (SD $0 \cdot 16$, range $0 \cdot 09-0 \cdot 66$ ) $\mathrm{mSv}$. 
Table 2. Fractional zinc absorption from semi-synthetic test meals containing different protein sources

(Mean values and standard deviations for eight subjects per study)

\begin{tabular}{|c|c|c|c|c|}
\hline \multirow[b]{2}{*}{ Study } & \multicolumn{2}{|c|}{$\begin{array}{c}\text { Test meal a (protein added) } \\
\mathrm{Zn} \text { absorption }(\%)\end{array}$} & \multicolumn{2}{|c|}{$\begin{array}{c}\text { Test meal } \mathrm{b} \text { (no protein added) } \\
\mathrm{Zn} \text { absorption }(\%)\end{array}$} \\
\hline & Mean & SD & Mean & SD \\
\hline Bovine whey & $44 \cdot 6$ & 8.8 & $42 \cdot 8$ & $10 \cdot 2$ \\
\hline Bovine casein & $41 \cdot 2$ & $7 \cdot 3$ & $47 \cdot 3$ & $9 \cdot 0$ \\
\hline BSA & $38 \cdot 0^{*}$ & 10.9 & 47.6 & $8 \cdot 4$ \\
\hline Egg albumen & $40 \cdot 5$ & $15 \cdot 4$ & $42 \cdot 6$ & $10 \cdot 3$ \\
\hline Soyabean isolate ${ }^{\dagger}$ & $33 \cdot 9 *$ & $12 \cdot 6$ & $45 \cdot 0$ & $11 \cdot 0$ \\
\hline
\end{tabular}

BSA, bovine serum albumin.

* Mean values were significantly different from those for the corresponding meal without protein $(P<0.05)$.

$\dagger$ Phytic acid content $<0.01 \mathrm{~g} / \mathrm{kg}$.

\section{DISCUSSION}

The results from the present study show that some isolated proteins, such as BSA and dephytinized soyabean-protein isolate, inhibit $\mathrm{Zn}$ absorption when added to a noninhibitory liquid meal. Other proteins, i.e. bovine whey, bovine casein and egg albumen had little or no effect on the $\mathrm{Zn}$ absorption. The inhibition by BSA and dephytinized soyabeanprotein isolate was found to be rather modest when compared with the effect of the same proteins on $\mathrm{Fe}$ absorption from identical test meals. For example, adding BSA to the same protein-free semi-synthetic test meal reduced Fe absorption almost $50 \%$ (Hurrell et al. 1990) while the inhibition of $\mathrm{Zn}$ absorption was approximately $20 \%$. Furthermore, in the present study, $\mathrm{Zn}$ absorption was reduced about $30 \%$ when dephytinized soyabean protein isolate was added to the protein-free liquid test meal. A similar dephytinized soyabeanprotein isolate reduced $\mathrm{Fe}$ absorption approximately $50 \%$ compared with a reference egg albumen test meal (Hurrell et al. 1992), which would be equivalent to about $85 \%$ lower Fe absorption than the protein-free test meal. A similar $85 \%$ reduction in Fe absorption was observed by adding bovine casein (Hurrell et al. 1990) although demineralized bovine whey and egg albumen were less inhibitory since Fe absorption was decreased about $65-70 \%$ (Hurrell et al. 1990). An important finding from the present study is thus that there is a difference between the influence of isolated proteins on the absorption of $\mathrm{Fe}$ and $\mathrm{Zn}$.

Our observations that proteins have either no effect or a negative effect on $\mathrm{Zn}$ absorption appear to be in contrast to the results of Sandström et al. (1980) and Kivistö et al. (1989). In both these studies a positive effect on $\mathrm{Zn}$ absorption was found by the addition of animal protein (cow's milk, cheese, beef or egg) to an inhibitory test meal based on wholemeal wheat bread (Sandström et al. 1980), or by the serving of a meal with high protein content together with an inhibitory test meal based on extruded bread (Kivistö et al. 1989). In the present study we found very little or no effect on $\mathrm{Zn}$ absorption when bovine whey, bovine casein or egg albumen were evaluated against a protein-free liquid meal containing no inhibitors of $\mathrm{Zn}$ absorption. The influence of dietary protein on $\mathrm{Zn}$ absorption thus seems to depend not only on the protein source, but also on the composition of the test meal with respect to the presence of inhibitors and enhancers of absorption.

The test meals used in earlier studies (Sandström et al. 1980; Kivistö et al. 1989) can be regarded as more complex matrices than the semi-synthetic test meal used in the present 
study. The mechanism for the positive effect on $\mathrm{Zn}$ absorption after the addition of protein to those inhibitory test meals is not known, but could possibly be related to the prevention of formation of non-absorbable $\mathrm{Zn}$-phytate complexes (Sandström et al. 1980). It seems unlikely that protein has a non-specific facilitating effect on $\mathrm{Zn}$ absorption since in the earlier study no increase in $\mathrm{Zn}$ absorption was observed from a test meal containing low amounts of phytic acid (Sandström et al. 1980). Thus, the previous findings, taken together with the results from the present study, indicate that the effect of protein on $\mathrm{Zn}$ absorption varies depending on the composition of the diet, in particular in relation to its content of phytic acid.

The present study, as well as earlier studies from our laboratory, used radio-isotopes administered to adult human subjects. The radionuclide technique employed has been described in detail earlier (Arvidsson et al. 1978). Instead of measuring the subjects in the whole-body counter immediately after intake of the labelled test meals, the $100 \%$ dose of radioactivity ingested by each subject was calculated as the difference between the measured activity in the test meal, minus activity in the leftovers measured after administration. This study design was chosen to overcome the uneven distribution within the body of the ingested isotope shortly after intake when the dose of radioactivity must still be regarded as a point source and, consequently, distributed differently as compared with whole-body retention measured $14 \mathrm{~d}$ after intake. Thus, a measurement of the ingested activity in vivo, by whole-body counting shortly after intake, cannot be regarded as a 'true' $100 \%$ retention measurement. Furthermore, the calculated $100 \%$ intake value (based on the measurements of labelled test meals before and after consumption) is adjusted to represent better the 'true' $100 \%$ whole-body retention value by the introduction of a correction factor for counting efficiency. The mean relative counting efficiency, i.e. the ratio between the count rate of a certain activity unevenly distributed in the body and the same activity measured in air at the centre of the counter, was found to be 0.889 when estimated by measurements of thirty-four subjects (Arvidsson et al. 1978). The individual variation was relatively small and the mean relative counting efficiency was judged to give sufficient accuracy. However, a systematic error is introduced by this study design, as would also be the case if a $100 \%$ value of the ingested dose was obtained immediately after ingestion. The error has been estimated to be at maximum $10 \%$ (A. Cederblad, personal communication 1994) which is relatively small, primarily due to the characteristics of the whole-body counter used in our studies which include large detectors and the choice of using the 'valley' spectral window (Arvidsson et al. 1978). Furthermore, all observations were paired, i.e. each subject acted as his or her own control. The evaluation of the results would thus be very little influenced by a systematic error in the measurement of the ingested ${ }^{65} \mathrm{Zn}$.

The isolated protein sources evaluated in the present study included the major nutritionally important proteins used in infant formulas which are bovine whey, casein, and soyabean-protein isolate. Our studies were made in adults so the effect of these proteins on $\mathrm{Zn}$ absorption during infancy cannot be projected with certainty. Techniques using stable isotopes are now available which make it possible to study the effect of different dietary components such as proteins on $\mathrm{Zn}$ absorption in infants. However, due to the much more elaborate study protocol needed including complete faecal collections over several days, this has not yet been done. If our results from studies in adults can be extrapolated to infants, it would seem that in order to ensure adequate $\mathrm{Zn}$ nutrition in formula-fed infants, formulas based on soyabean isolate, even after dephytinization, should contain higher levels of $\mathrm{Zn}$ than cow's milk formulas. 


\section{REFERENCES}

Arvidsson, B., Cederblad, A., Björn-Rasmussen, E. \& Sandström, B. (1978). A radionuclide technique for studies of zinc absorption in man. International Journal of Nuclear Medicine and Biology 5, 104-109.

Cook, J. D. \& Monsen, E. R. (1976). Food iron absorption in human subjects. III. Comparison of the effect of animal proteins on nonheme iron absorption. American Journal of Clinical Nutrition 29, 859-867.

Hurrell, R. F., Berrocal, R., Lynch, S. R., Dassenko, S. A. \& Cook, J. D. (1990). The influence of bovine milk proteins on iron absorption in man. In Recent Knowledge on Iron and Folate Deficiencies in the World, pp. 265-273 [S. Hercberg, P. Galan and H. Dupin, editors]. Paris: Colloque INSERM.

Hurrell, R. F., Juillerat, M.-A., Reddy, M. B., Lynch, S. R., Dassenko, S. A. \& Cook, J. D. (1992). Soy protein, phytate and iron absorption in humans. American Journal of Clinical Nutrition 56, 573-578.

Hurrell, R. F., Lynch, S. R., Trinidad, T. P., Dassenko, S. A. \& Cook, J. D. (1988). Iron absorption in humans: bovine serum albumin compared with beef muscle and egg white. American Journal of Clinical Nutrition 47, $102-107$.

Hurrell, R. F., Lynch, S. R., Trinidad, T. P., Dassenko, S. A. \& Cook, J. D. (1989). Iron absorption in humans as influenced by bovine milk proteins. American Journal of Clinical Nutrition 49, 546-552.

International Commission on Radiological Protection (1987). ICRP publication 53. Radiation dose to patients from radiopharmaceuticals. Annals of the ICRP 18, $1-4$.

Kivistö, B., Cederblad, A., Davidsson, L., Sandberg, A.-S. \& Sandström, B. (1989). Effect of meal composition and phytate content on zinc absorption in humans from an extruded bran product. Journal of Cereal Science 10, $189-197$.

Lönnerdal, B., Cederblad, A., Davidsson, L. \& Sandström, B. (1984). The effect of individual components of soy formula and cow's milk formula on zinc bioavailability. American Journal of Clinical Nutrition 40, 1064-1070.

Lynch, S. R., Dassenko, S. A., Cook, J. D., Juillerat, M.-A. \& Hurrell, R. F. (1995). Inhibitory effect of a soybean-protein related moiety on iron absorption in humans. American Journal of Clinical Nutrition $\mathbf{6 0}$, $567-572$.

Makover, R. U. (1970). Extraction and determination of phytic acid in beans. Cereal Chemistry 47, $288-296$.

Nävert, B., Sandström, B. \& Cederblad, A. (1985). Reduction of the phytate content of bran by leavening in bread and its effect on absorption of zinc in man. British Journal of Nutrition 53, 47-53.

Sandström, B., Arvidsson, B., Cederblad, A. \& Björn-Rasmussen, E. (1980). Zinc absorption from composite meals. I. The significance of wheat extraction rate, zinc, calcium, and protein content in meals based on bread. American Journal of Clinical Nutrition 33, 739-745.

Sandström, B. \& Cederblad, A. (1980). Zinc absorption from composite meals. II. Influence of the main protein source. American Journal of Clinical Nutrition 33, 1778-1783.

Sandström, B., Cederblad, A. \& Lönnerdal, B. (1983). Zinc absorption from human milk, cow's milk and infant formulas. American Journal of Diseases in Children 137, 726-729.

Sandström, B., Davidsson, L., Cederblad, A. \& Lönnerdal, B. (1985). Oral iron, dietary ligands and zinc absorption. Journal of Nutrition 115, $411-414$. 